Article Title: Gettysburg Inc.: The Use and Abuse of an Historical Icon

Authors: Oliver Gruner and Dan McCabe

Abstract: A combination of image, text, historical reflection and political commentary, this graphic research article explores the use and abuse of Abraham Lincoln's Gettysburg Address within the US public sphere. In 155 years since Lincoln gave this speech, his words have been subsumed into all manner of heated debates on issues such as race, class, international relations and the Civil War's legacy. Indeed, as Barry Schwartz argues, the Address's figurative power lies not in a single interpretation, but in the way in which successive generations reinterpret it 'in light of new situations and challenges'. From Woodrow Wilson to Franklin Roosevelt, Richard Nixon to Donald Trump, it has continually served as a rhetorical battleground upon which arbiters of various political persuasions wage war over the meaning of American democracy - past, present and future. When soonto-be President Trump delivered his 'Contract with the American Voter' at Gettysburg in October 2016, he was but the latest in a long line of politicians to put the Address's symbolic power in the service of his own ideological ends. 'Every salesman needs a pitch' writes the historian Jared Peatman. 'And over time, increasing numbers of Americans came to see the Gettysburg Address as the most effective way to sell the ideals of this country, both internally and externally'.

A collaboration between a graphic designer and visual culture historian, Gettysburg Inc. is a satirical rendering of the Gettysburg Address for the contemporary era. Taking the form of a sleek corporate brochure, this article explores the disconnect between words and deeds, truth and fiction, democratic ideals and the political process. Visually, we draw on the "hand 
of Lincoln' motif, central to the president's visual mediation in historical paintings, sketches, political campaign posters, advertisements and sculptures. Appropriating and reframing words, images and events from the recent past, we engage with ideas on the politics of collective memory, and the symbiotic relationship between memory and 'forgetting'. A piece of critical design, Gettysburg Inc. is a reflection on the unstable nature of collective memory, and an exploration of the ways in which graphic design can engage with, and offer new perspectives on, history and politics.

Keywords: graphic design, Gettysburg Address, public memory, politics, Abraham Lincoln critical design 


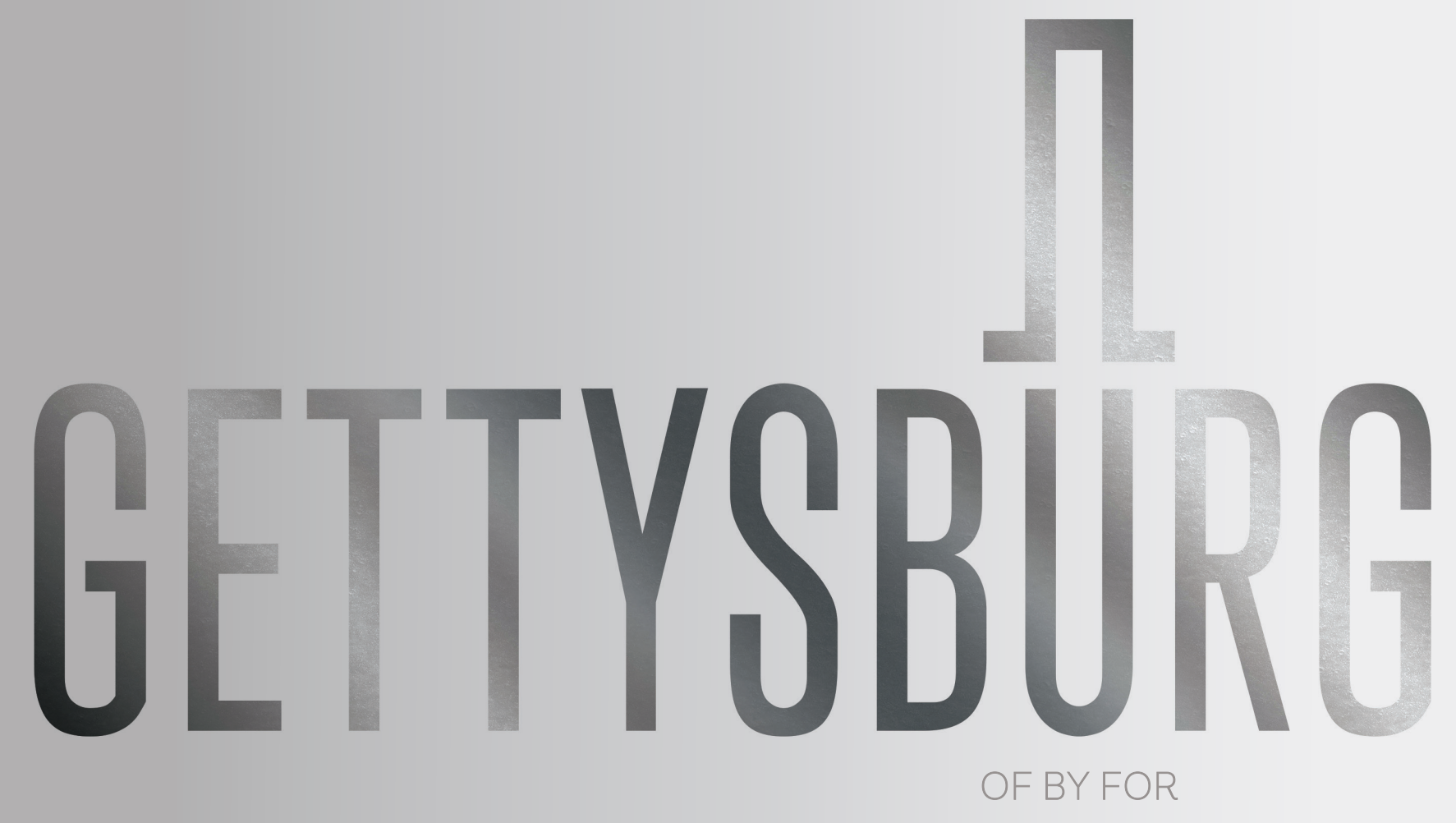


Four score and seven years ago our fathers brought forth on this continent, a new nation, conceived in Liberty, and dedicated to the proposition that all men are created equal.

Now we are engaged in a great civil war, testing whether that nation, or any nation so conceived and so dedicated, can long endure. We are met on a great battle-field of that war. We have come to dedicate a portion of that field, as a final resting place come to dedhere gave their lives that thas nation might live. It is altogether fitting and proper that we should do this.

But, in a larger sense, we can not dedicate - we can not consecrate - we can not hallow - this ground. The brave men, living and dead, who struggled here, have consecrated it, far above our poor power to add or detract. The world will little note, nor long remember what we say here, but it can never forget what they did here. It is for us the living, rather, to be dedicated here to the unfinished work which they who fought here have thus far so nobly advanced. It is rather for us to be here dedicated to the great task remaining before us that from these honored dead we take increased devotion to that cause for which they gave the last full measure of devotion - that we here highly resolve that these dead shall not have died in vain that this nation, under God, shall have a new birth of freedom - and that government of the people, by the people, for the people, shall not perish from the earth.

\section{Abraham Lincoln}




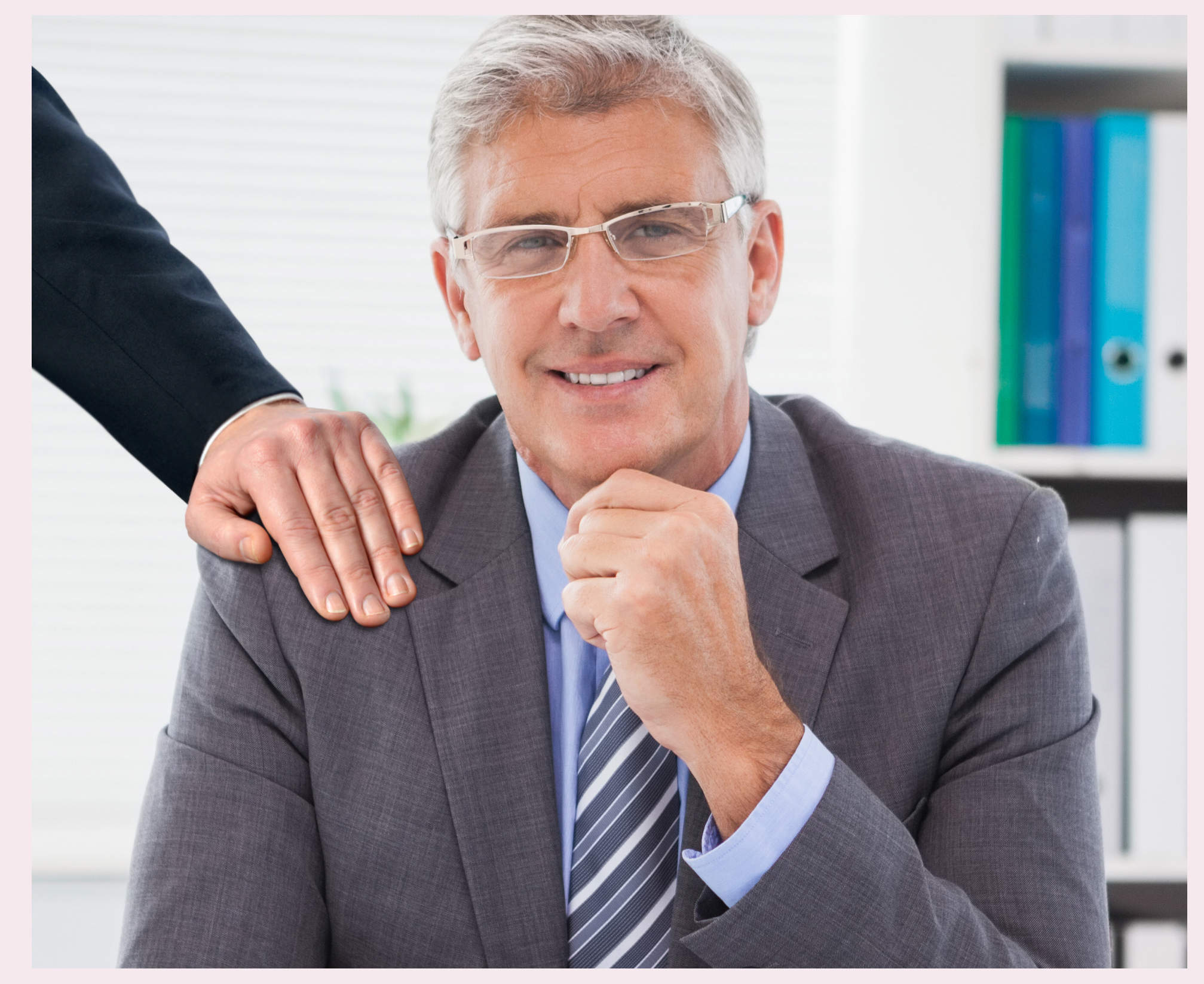

A warm welcome from our

commander in chief, Bill Saunders

In the space of 272 words, Abraham Lincoln transformed America, bequeathing to his nation (our nation) its identity, its philosophy, its creed. The Gettysburg Address was Lincoln's gift to us all. Inspiration wrapped in crystalline prose, it offered hope during the Civil War's darkest days. Around 155 years later, the passage of time has done little to blunt that hetoric: Four score and seven years ago,' a new bicth of freedom. Even as the smoke lifted at Fort Sumter, Shiloh and Bull Run, those 272 words were soaring into the hearts of citizens across the land. On Gettysburg's hallowed ground, Lincoln, as one of our finest cholars, Garry Wills, observed, 'wove a spell that has not, yet, been broken?

I for one am still enchanted.

Imagine a kid of 19 , fresh out of business schoo Whe a buing desire to do sorming school with his life. It wasn't quite four score and seven years ago (whatever my younger colleagues say).

but it sure feels like it. With empty pockets and a head full of ideas, I became CEO of Gettysburg Inc. Building this company from nothing hasn't been plain sailing. But as Abe Lincoln discovered, and as we at Gettysburg Inc. understand, nothing worth doing ever is. Increased devotion is what Lincoln asked of his countrymen. And that's what we strive for, every day. We know that you do too.

Sometimes, though, even the dedicated need helping hand. Where would Lincoln have been

without his allies, his Secretary of State William

H. Seward, his treasurer Salmon P. Chase? Would

he have unlocked his full potential without a team watching his back? It's a tough world out there,

but with Gettysburg Inc. on your side you have a design for life. We promise that an investment in our bespoke services, solutions and products is an investment in you. Let us be your helping hand let us go forward together; and most of all let us assist you in that search for clarity, creativity and vision - that Gettysburg - that resides within us all.

Yours truly,

Bill Saunders

CEO Gettysburg Inc 
I should be glad, if I could flatter myself that I came as near to the central idea of the occasion, in two hours, as you did in two minutes.

We all lead busy lives. But are we busy living?

A dinner-date cancelled as the paperwork piles up. Civil War. Only at Gettysburg could he synergize Meeting overrun - there goes Sally's school play. They grow up fast...

these interests, announcing to the world: this is what counts.

When you feel ready to cut out the noise, and to long before most of his generation, the importance dedicate yourself to the important things in life, of streamlining. And he had quite a portfolio: the you know you've reached Gettysburg.

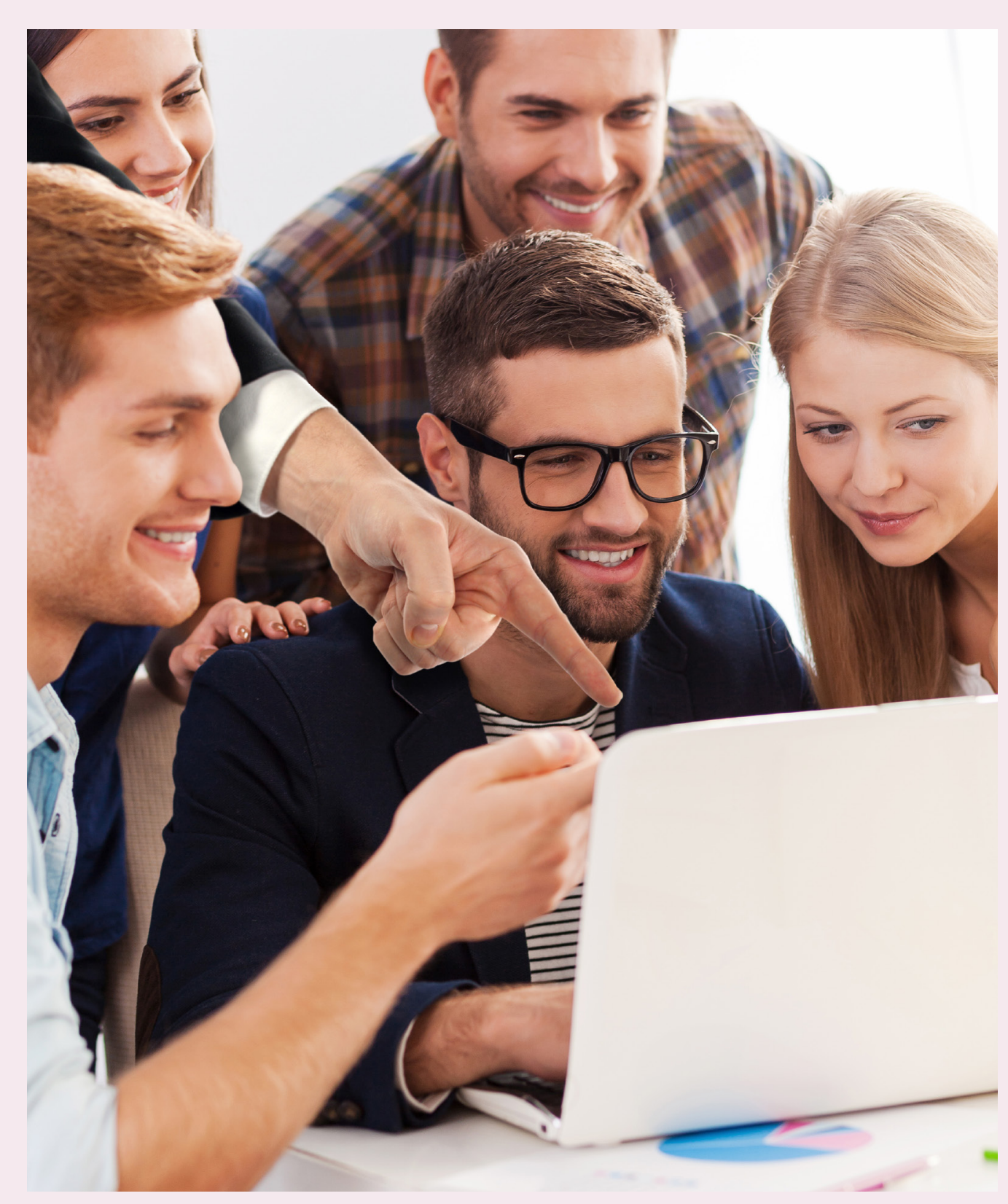


A contract with promise
Today you could shake the hand that shook the hand...that shook the hand of Abraham Lincoln.

Hard to imagine, I know. Sometimes we can feel disconnected from the people who really matter. When, in 1913, Presiden Wo Gettysburg veterans on the battle's 50th anniversary hecould texplain why anyone had elected him in the first place: I have been chosen the leader of the Nation. sumy out soit has come about, and herelstand: Tritter days. But in his game-changing theditiothe Gettysburg creed ("peace and union and vigor the matuity and might of a great nation') Wilson cascaded the secret of Lincoln's message down to his fellow Americans And in doing so, found who we at Gettysburg inc, call Congsing
That was a century ago. It's a different world now, facing new global challenges. Whether you're in the business of building bridges, building walls or breaking them down, your cause is ours.

We know that laying yourself on the line is daunting Whe (a) are staning head and shoulders, Lincoln-like, you your of talented experts with our advanced networking fol Toted number one in cyber futures 2017, * Or link "

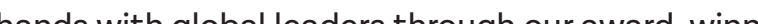
rd-winning evgenysburg

We're proud to serve. Our trained advisors offer impartial advice without the jargon. We're clear Gettysburg clear. "Our CEO Bill Saunders can claim Civil War hero, General Ulysses S. Grant,
a distant blood relation. As Bill often tells us, weve got Uncle Sam buitt 


$$
2 x^{5}
$$




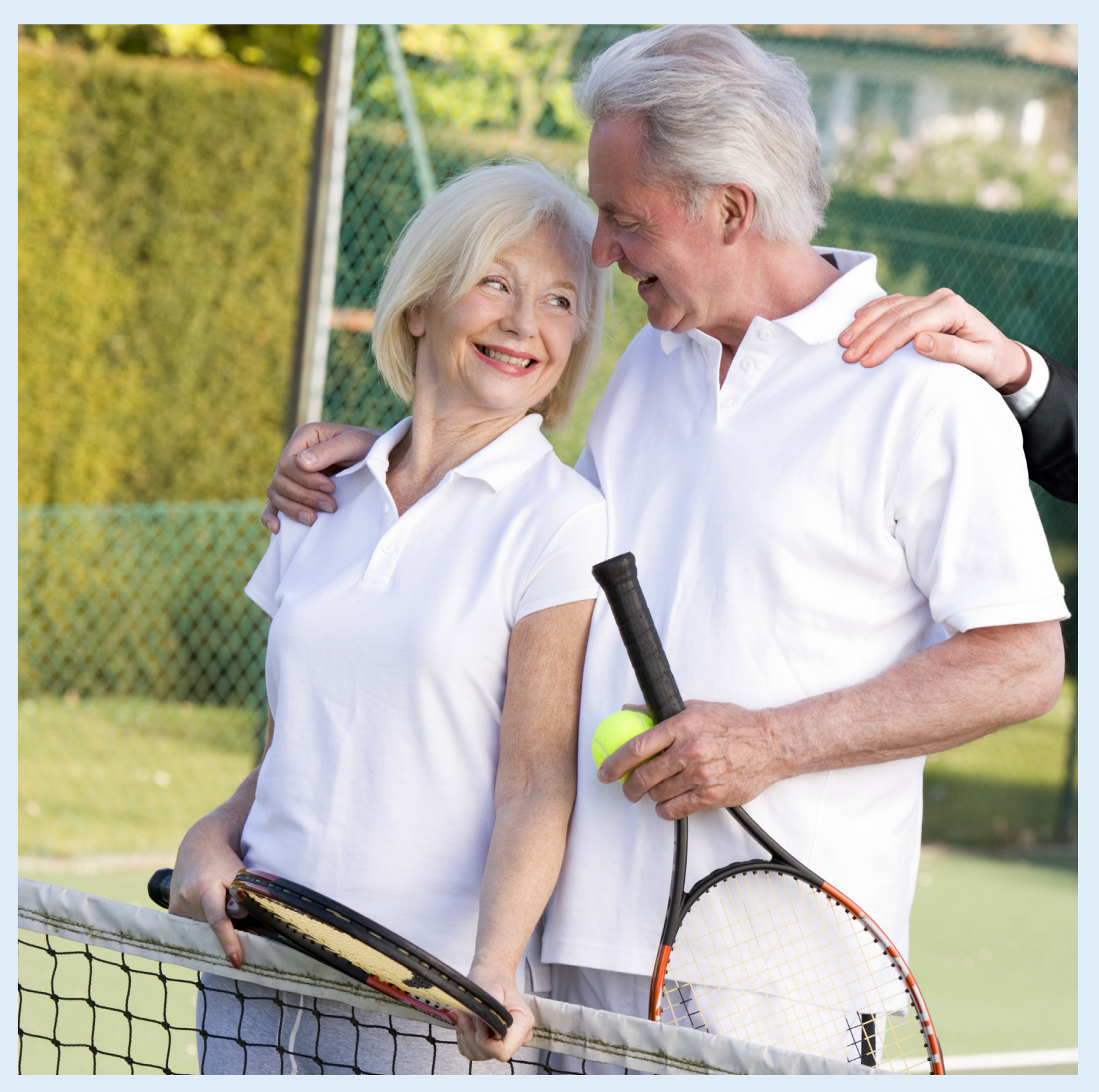

There with you, always
Any transition can be tough, and it's vital to prepare you and your loved ones for all eventualities.

At Gettysburg Cemetery in 1863, Abraham Lincoln's rhetoric far transcended that of the standard funeral oration. Above all else Gettysburg was about human potential. In those 'honored dead, America's sixteenth President prophesied a shimmering new world, one which resonates with us still.

It only takes a little joined up thinking to see the connections here. Perhaps it was a paradigm shift in Lincoln's time, but today we know the game never ends - only the playbook changes. When President Richard M. Nixon addressed anti-war protestors on the steps of the Lincoln Memorial in May 1970 he had his own challenges with which to contend: Vietnam, Cambodia, Kent State (and our kids think they have it tough!). But harnessing the power of Gettysburg, Nixon broke in his own words 'matters of the spirit'.

Two years later and China was open for business. At Gettysburg Inc. we know that it's easy for a bump in the road to set us offity Wefth offices in all major your side with in the hour, wher Tha's a Gettyshurg promise. 
Have you ever listened to the actor Charles Laughton recite the Gettysburg Address? What about Gregory Peck, or, our favorte here at Gettysburg Inc., Daniel Day Lewis? It's easy to get caught up in those dulcet

It's okay to want a little reassurance now and then. Great speeches, like great businesses, are sometimes just about giving peace of mind.

Join a Gettysburg Preparation Plan today and you're joining the millions of men and women who now dedicate themselves to Transcendence ${ }^{\mathrm{T} w}$

Quote SURVIVAL on registration and enjoy a 30 per cent members discount.
The bitterness of the fight has faded for me. I only feel the love of country, the satisfaction of giving my life for it... I would like to put my hand in Abraham Lincoln's. 
Lincoln always knew that the Gettysburg Address was a work in progress - a great task lay before him. And he would face that task with all the fire and fury bequeathed to our presidents by that little thing we call Democracy ${ }^{T w}$. Years speed by, governments come and go, big ideas are in and out of fashion. It's a messy

A new birth

come and go, big ideas are in and out of fashion. It's a messy

the system can seem rigged against you; broken, even. If only

someone could declutter your perspective, hack through the forest,

drain the swamp and help you plant the seeds of your future vision.

All this is possible with Amendments 2.0, cutting edge predictive technology developed at our labs. Benefitting from the latest research in financial futures, image management, crisis-proofing and cryogenic capabilities, there will be nothing standing in the way of you and your dreams. The world's moving in unexpected directions, but our customers always come home to Gettysburg.

And it's true what they say. Positive change really does begin at home. We at Gettysburg linc. promise to corthue beschmarking our services against those of our competitors, so that you don't have to. Well never stop enhancing our solutions in line with your needs. Formed of dedicated professionals, led by a passionate CEO, ready for the future - Gettysburg Inc.

Visit our website to find out more: www.gettysburginc.info Or let's touch base offline: 01863 LINCOLN

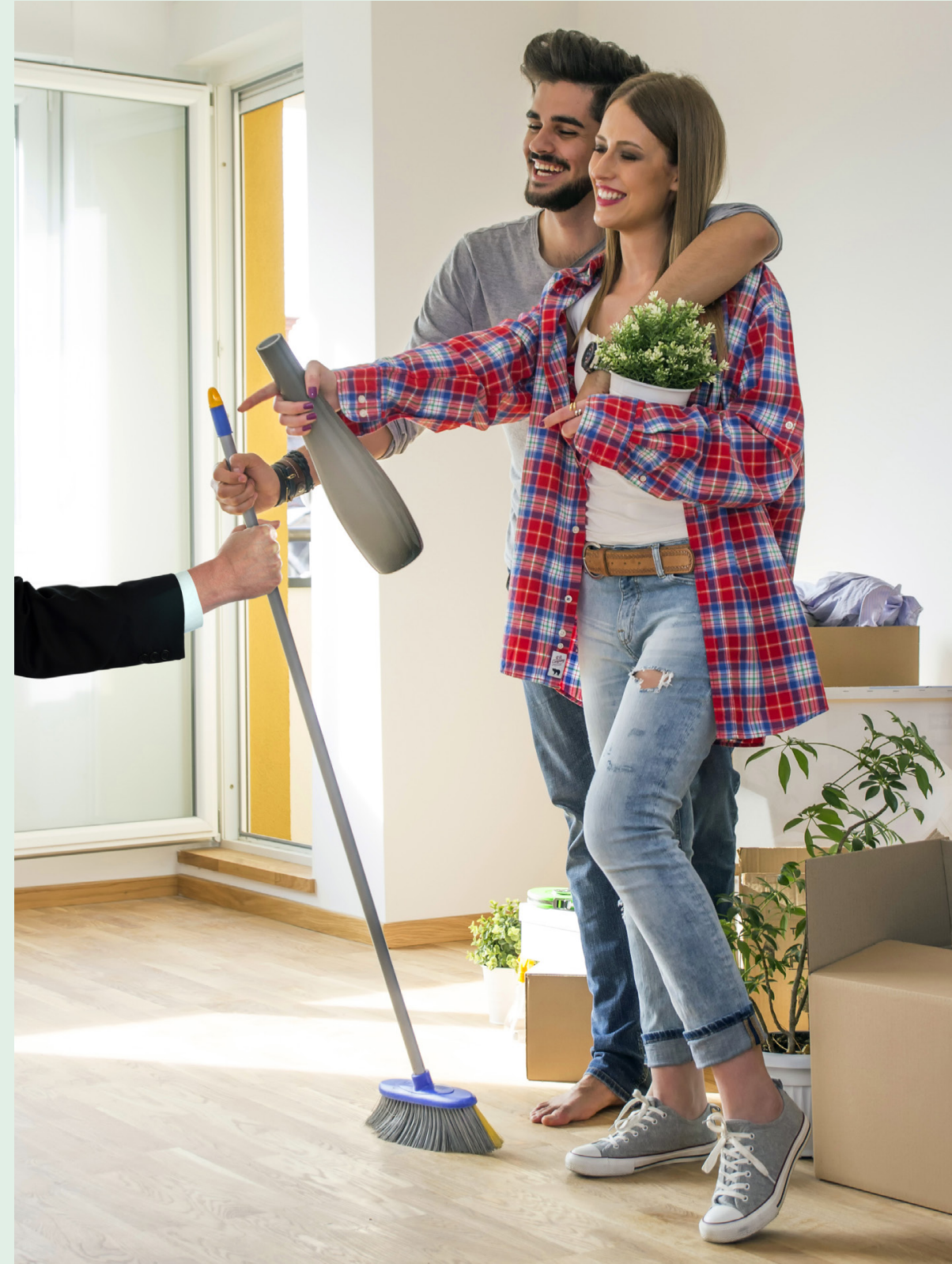


Gettysburg Inc. small print

Page 1. 'Four score and seven years ago [...' Gettysburg Inc. believes the
'Bliss Copy' of the Gettysburg Address to be the most authoritative 'Bliss Copy' version of Lincoin's speech, and that which most accurately chimes wh Page Page 3. 'AA]s one of our finest scholars, Garry Wills, observed [...' (1992:
175). Our CEO Bill Saunders keeps a pristine copy of the book on a shelf above his desk.

Page 4. 'I should be glad, if 1 could flatter myself [...]' Edward Everett to Abraham Lincoln, 20 November 1863. In Roy P. Baster (1953: 25). NB Customer testimonials are representative of, but not directly related to

Page 7. 'When, in 1913, President Woodrow Wilson [...'? Woodrow Wilson,
Address at Gettysburg (1913). Bill Saunders spent much of the 1980 s studying corporate innovation at a 'Quality Dojo' in New Mexico. It was speech and was impressed by tos war: "How wholesome and healing the peace has been'. With its avoidad of Gettysburg's more controversial elements, Wilson's speech - and, general, popular Gettysburg remembrance of the early 20 th century -
Page 7. 'A team of rivals [...'”' As many in politics and business will tell you, Doris Kearns Goodwin's Team of Rivals: The Political Genius of Abraham Lincoln (2005) is a supreme study in leadership. Bill famously gives th

Page 11. '....] matters of the spirit'.' Quoted in Bruce Oudes (1989: 127).

hough he neter hone on several occasions. According to Bill, they mainly talked about their shared passion - football.

age 13: The bitterness of the fight has faded for me .... Mary Raymond Shipman Andrews (1906: 24).

Gettysburg Inc. legal statement

All images have been purchased and edited in accordance with

Shutterstock standard licence guidelines. All characters, and incidents

persons (living or deceased), places, buildings, and products is intended

or should be inferred. No person or entity associated with this brochure

received payment or anything of value, or entered into any agreement, in
connection with Gettysburg Inc. No animals were harmed in the making
Brocher webs ive time for nore

lets agu pored

lanch of $B B^{g}$ 


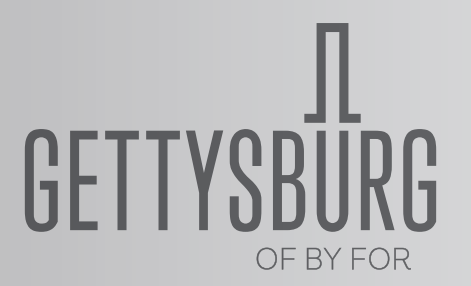

Gettysburg Inc. ${ }^{\text {TM }} 2018$

www.gettysburginc.info 


\section{References}

Andrews, M. R. S. (1906), 'The perfect tribute', Scribners, 40:1, pp. 17-24

Basler, R. P. (ed.) (1953), The Collected Works of Abraham Lincoln: VII, New Brunswick, NJ: Rutgers University Press.

Goodwin, D. K. (2005), Team of Rivals: The Political Genius of Abraham Lincoln, New York: Simon and Schuster.

Kammen, M. (1991), Mystic Chords of Memory: The Transformation of Tradition in American Culture, New York: Vintage Books.

Oudes, B. (ed.) (1989), From: The President: Richard Nixon's Secret Files, New York: Harpercollins.

Peatman, J. (2013), The Long Shadow of Lincoln's Gettysburg Address, Carbondale: Southern Illinois University Press.

Schwartz, B. (1996), 'Rereading the Gettysburg Address: Social change and collective memory', Qualitative Sociology, 19:3, pp. 395-422.

(2000), Abraham Lincoln and the Forge of National Memory, Chicago: The University of Chicago Press.

(2008), Abraham Lincoln in the Post-Heroic Era: History and Memory in Late TwentiethCentury America, Chicago: University of Chicago Press.

Sturken, M. (1997), Tangled Memories: The Vietnam War, the AIDs Epidemic and the Politics of Remembering, Berkeley: University of California Press. 
Thomas, C. A. (2002), The Lincoln Memorial and American Life, Princeton: Princeton University Press.

Wills, G. (1992), Lincoln At Gettysburg: The Words That Remade America, New York: Simon and Schuster.

Wilson, W. (1913), 'Address at Gettysburg', 4 July, The American Presidency Project, http://www.presidency.ucsb.edu/ws/?pid=65370. Accessed January 3, 2018.

\section{Contributor Details}

Oliver Gruner is a senior lecturer in visual culture at the University of Portsmouth. His research explores politics and cultural memory, in particular the ways in which the US past has been represented and 'remembered' in film, comics and other visual media. He is the author of Screening the Sixties: Hollywood Cinema and the Politics of Memory (Palgrave Macmillan, 2016), and has had essays published in various journals and edited collections. He is currently developing a series of collaborative projects that bring together historians and visual practitioners to explore new ways of visualizing history.

Dan McCabe is a senior lecturer in graphic design at the University of Portsmouth. He has worked in industry as both a full-time and freelance practitioner, predominantly within the fields of packaging and branding. His current research interests are focused on exploring the existence of heraldic language within twenty-first century British society. This includes looking at how heraldic language is used in corporate and cultural branding, and the parallels between the ancient practice of heraldry and the contemporary practice of brand identity design. 